\title{
Carbon-based Fuel Cell
}

\section{Final Report}

\section{June 1, 2003 - July 30, 2005}

\author{
Steven S. C. Chuang \\ February 12, 2006
}

Department of Chemical Engineering, The University of Akron 200 East Buchtel Commons

Akron, $\mathrm{OH}, 44325-3906$

Phone number: 330-972-6993; Fax number: 330-972-5856

E-mail: schuang@uakron.edu

DE-PS26-03NT41803 


\section{Disclaimer}

This report was prepared as an account of work sponsored by an agency of the United States Government. Neither the United States Government nor any agency thereof, nor any of their employees, makes any warranty express or implied, or assumes any legal liability or responsibility for the accuracy, completeness, or usefulness of any information, apparatus, product, or process disclosed, or represents that its use would not infringe privately owned rights. Reference herein to any specific commercial product, process, or service by trade name, trademark, manufacturer, or otherwise does not necessarily constitute or imply its endorsement, recommendation, or favoring by the United States Government or any agency thereof. The views and opinions of authors expressed herein do not necessarily state or reflect those of the United States Government or any agency thereof. 


\begin{abstract}
The direct use of coal in the solid oxide fuel cell to generate electricity is an innovative concept for power generation. The $\mathrm{C}$-fuel cell (carbon-based fuel cell) could offer significant advantages: (i) minimization of NOx emissions due to its operating temperature range of $700-$ $1000{ }^{\circ} \mathrm{C}$, (ii) high overall efficiency because of the direct conversion of coal to $\mathrm{CO}_{2}$, and (iii) the production of a nearly pure $\mathrm{CO}_{2}$ exhaust stream for the direct $\mathrm{CO}_{2}$ sequestration. The objective of this project is to determine the technical feasibility of using a highly active anode catalyst in a solid oxide fuel for the direct electrochemical oxidation of coal to produce electricity. Results of this study showed that the electric power generation from Ohio No 5 coal (Lower Kittanning) Seam, Mahoning County, is higher than those of coal gas and pure methane on a solid oxide fuel cell assembly with a promoted metal anode catalyst at $950{ }^{\circ} \mathrm{C}$. Further study is needed to test the long term activity, selectivity, and stability of anode catalysts.
\end{abstract}




\section{TABLE OF CONTENTS}

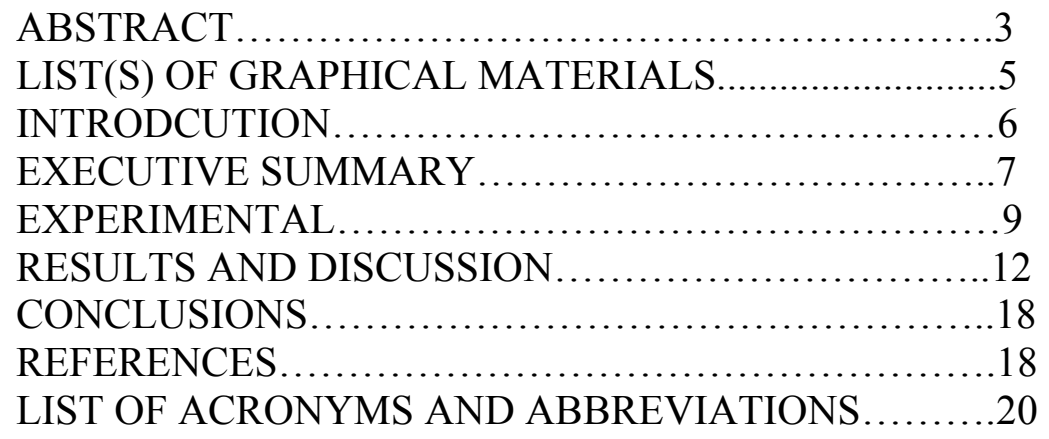




\section{LIST(S) OF GRAPHICAL MATERIALS}

Figure 1. The relationship between fuel processing and fuel cells......................8

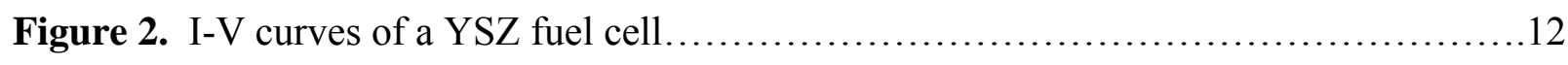

Figure 3. I-V for petroleum coke and fuel mixtures for a Ni-based anode SOFC at $900{ }^{\circ} \mathrm{C} \ldots 15$

Figure 4. I-V for petroleum coke and fuel mixtures for a Ni-based anode $\mathrm{SOFC}$ at $950{ }^{\circ} \mathrm{C} \ldots 16$

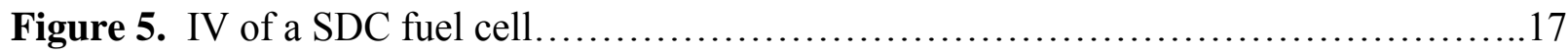




\section{INTRODUCTION}

Fuel cell is a device which allows the direct conversion of fuel to electric power. Solid oxide fuel cell (SOFC) holds a great promise for electric power generation due to its more flexibility in fuel usage than PEM fuel cell. The current solid oxide fuel cell system involves (i) use of natural gas or diesel fuel as a feed to a reformer for the production of syngas (a mixture of $\mathrm{CO}$ and $\mathrm{H}_{2}$ ), (ii) cleaning of syngas, and (iii) the injection of syngas to the SOFC for the generation of the DC electricity.

The basic principle of the operation of the SOFC using syngas as the feed involves (i) a cathodic reaction: $\mathrm{O}_{2}+2 \mathrm{e}^{-} \rightarrow \mathrm{O}^{2-}$; (ii) the diffusion of the $\mathrm{O}^{2-}$ from the cathode to the anode through a solid electrolyte; and the anodic reaction (i.e., the electrochemical oxidation of $\mathrm{CO}$ and $\mathrm{H}_{2}$ ) to produce electricity. The electrochemical oxidation of $\mathrm{CO}$ and $\mathrm{H}_{2}$ can be written as follows:

$\mathrm{H}_{2}+\mathrm{O}^{2-} \quad \longrightarrow \quad \mathrm{H}_{2} \mathrm{O}+2 e^{-}$
$\mathrm{CO}+\mathrm{O}^{2-} \quad \longrightarrow \quad \mathrm{CO}_{2}+2 e^{-}$

The general requirement for generating electricity on the anode is the electrochemical oxidation of a fuel. This project was intended to determine the feasibility of developing an effective catalyst for catalyzing the electrochemical oxidation reaction of a solid carbon fuel. The reaction is written as below.

$$
\mathrm{C}+2 \mathrm{O}^{2-} \longrightarrow \mathrm{CO}_{2}+4 \mathrm{e}^{-}
$$

The development of a fuel cell which can directly utilize solid carbon could provide a number of significant advantages in the fuel cell system for the electric power generation. These advantages include the direct use of coal as the fuel and simplifying the fuel cell system by eliminating the fuel reforming steps. 


\section{EXECUTIVE SUMMARY}

The objective of this phase I innovative project is to determine the technical feasibility of using coal as the fuel for a solid oxide fuel cell. This type of C-fuel cell (carbon-based fuel cell) could offer significant advantages: (i) minimization of $\mathrm{NO}_{\mathrm{x}}$ emission due to the operating temperature range of $700-1000{ }^{\circ} \mathrm{C}$, (ii) high overall efficiency because of the direct conversion of carbon to $\mathrm{CO}_{2}$, (iii) low investment and maintenance cost due to simplicity of the process, and (iv) easy of $\mathrm{CO}_{2}$ sequestration due to the production of $99 \%$ purity of $\mathrm{CO}_{2}{ }^{1,2}$

Coal contains solid carbon, a variety of volatile hydrocarbons, heavy metals, metal oxides, and sulfur compounds. The key issue addressed in this project is whether the direct contact between the solid coal particle and the anode catalyst surface could lead to the direct electrochemical oxidation of carbon in the content of the coal particles.

\section{Approach}

- Develop an anode catalyst to promote the electrochemical oxidation of coal.

o Use a cold-pressing technique to fabricate the electrolyte thin film.

o Use a screen-printing technique to attach a cathode and an anode on the electrolyte.

- Use mass spectroscopy and infrared spectroscopy to monitor the composition of the effluents from the fuel cell.

- Measure the current and voltage output.

- Characterize the electrolyte, cathode, and anode materials with X-ray diffraction.

\section{Accomplishments}

- Design and construction of a solid oxide fuel cell which produced $100 \mathrm{~mA} / \mathrm{cm}^{2}$ at $0.6 \mathrm{~V}$ using Ohio\#5 coal as the fuel.

- Successful test of the solid oxide fuel cell for the direct oxidation of methane.

- Test of the solid oxide fuel cell using hydrogen, methane, heptane, activated carbon, petroleum coke, and Ohio \# 5 coal as fuels.

- Successful fabrication of intermediate temperature SOFC using SDC (i.e., Samariumdoped Ceria $\left.\left(\mathrm{Sm}_{0.2} \mathrm{Ce}_{0.8} \mathrm{O}_{1.9}\right)\right)$ as the electrolyte and SSC (i.e., Strontium-doped Samarium Cobaltite $\left.\left(\mathrm{Sm}_{0.5} \mathrm{Sr}_{0.5} \mathrm{CoO}_{3}\right)\right)$ as the cathode.

- The fuel cell using Pt as the anode, SDC as the electrolyte, and SSC as the cathode produced $100 \mathrm{~mA} / \mathrm{cm}^{2}$ at $0.4 \mathrm{~V}$ using $\mathrm{H}_{2}$ as the fuel at $700{ }^{\circ} \mathrm{C} ; 200 \mathrm{~mA} / \mathrm{cm}^{2}$ at $0.6 \mathrm{~V}$ at $800{ }^{\circ} \mathrm{C}$.

Although the initial work for this study showed that the direct contact between the pulverized coal particle and the anode catalyst surface led to generation of the electricity and $\mathrm{CO}_{2}$, no long term study on the anode catalyst activity, selectivity, and deactivation characteristics has been done due to the batch operation mode of the laboratory scale fuel cell. The major challenges in this research include the fabrication of the anode-supported fuel cell and sealing of the fuel cell reactor. Difference in thermal expansion coefficients of the various catalyst and electrolyte components usually leads to the cracking of the fuel cell during thermal cycling. Further improvement is needed on the fabrication approaches for the fuel cell and refinement of the 
anode catalyst structure and composition. The successful development of this proposed technology could eliminate the use of coal-fired boilers for power generation. ${ }^{3}$

The significance of this proposed direct coal fuel cell technology can be further illustrated by Figure 1 which summarizes the relationship between the fuel types and currently available fuel cell technologies. Although the low-temperature fuel cells (PEMFC and PAFC) perform well with $\mathrm{H}_{2}$ fuel inputs, the need to generate highly purified $\mathrm{H}_{2}$ from various feedstocks such as natural gas and coal brings major equipment complexities into the fuel cell systems, resulting in overall efficiency loss and significant cost penalties. ${ }^{4,5}$ The direct coal (i.e., carbon) SOFC technology will allow the direct use of coal without complications from the operation of coal gasification, water-gas shift, and selective $\mathrm{CO}$ oxidation reactors. The proposed direct carbon based fuel cell technology could lead to a low cost approach for generation of electricity from coal with high purity $\mathrm{CO}_{2}$ as a byproduct.

Figure 1. The relationship between fuel processing and fuel cells

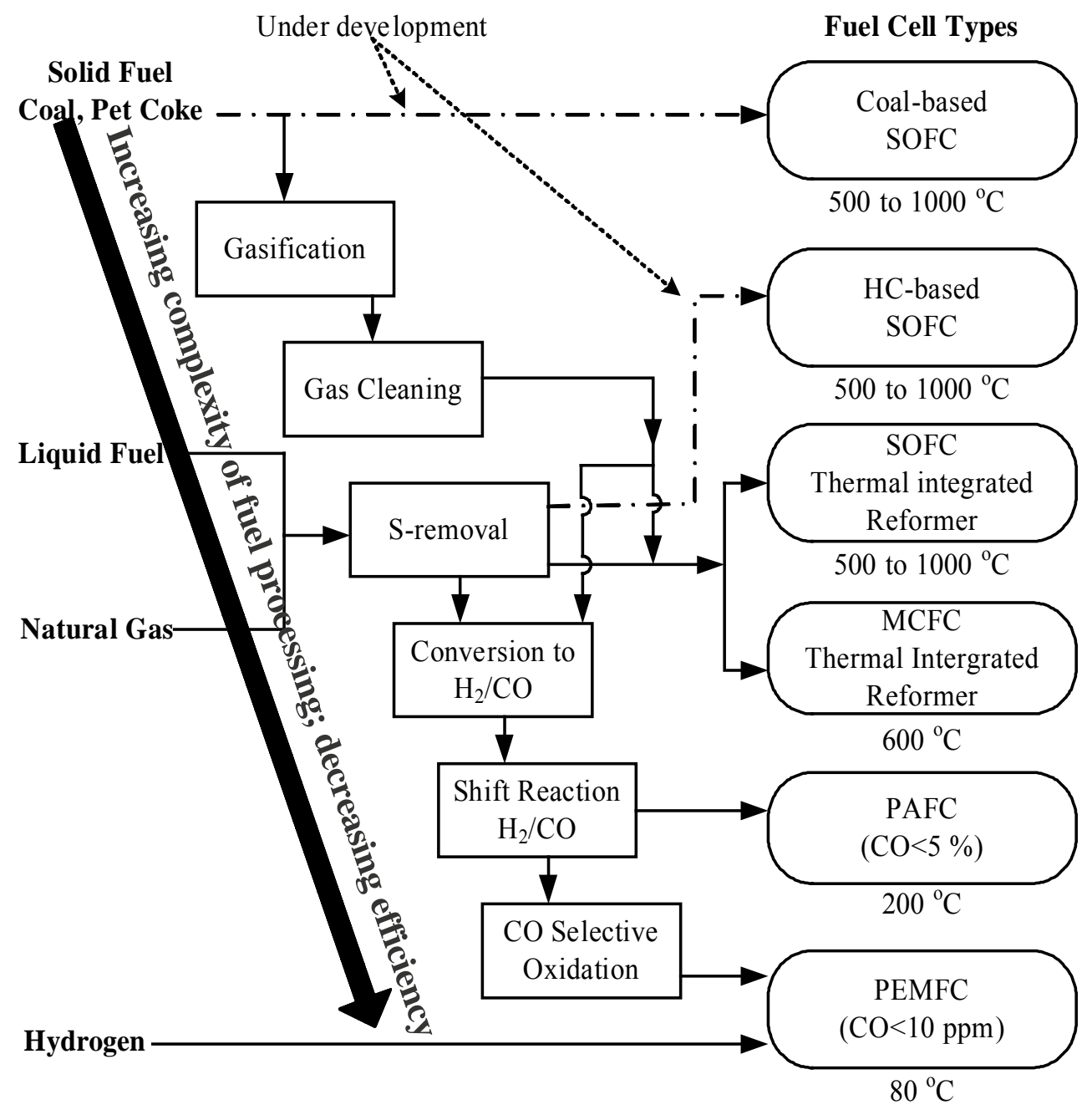

Ref: N.F. Brandon, S. Skinner, B.C.H. Steele, Annu. Rev. Mater. Res. 2003. 33:183-213 


\section{EXPERIMENTAL}

\section{High temperature YSZ electrolyte fuel cell}

A solid oxide fuel cell system with a LSM/YSZ/Metal disk was set up. LSM $\left(\mathrm{La}_{0.7} \mathrm{Sr}_{0.3} \mathrm{MnO}_{3}\right)$ was prepared by a solgel process involving dissolving metal salts in an ammonium-EDTA solution. ${ }^{6}$ The YSZ solid electrolyte disc was custom-manufactured from TOSOH Corporation using $8 \%$ dense YSZ powder. The anode catalyst was prepared by impregnating aqueous solution of metal nitrates onto porous YSZ fibers obtained from Zircar Inc. The reaction temperature required for the electrochemical oxidation of coal to take place thereby defines the minimum operating temperature of the $\mathrm{C}$-fuel cell.

\section{Fabrication of SDC electrolytes and SSC cathodes intermediate temperature SOFCs}

Since the YSZ fuel cell has to operate above $850{ }^{\circ} \mathrm{C}$ to obtain a sufficient power density, an extensive effort was devoted toward fabricating intermediate temperature $\left(\sim 600-800{ }^{\circ} \mathrm{C}\right)$ solid oxide fuel cells using samarium-doped ceria (i.e., SDC) electrolytes with a $20 \%$ mol samarium dopant content $\left(\mathrm{Sm}_{0.2} \mathrm{Ce}_{0.8} \mathrm{O}_{1.9}\right)$ and strontium-doped samarium cobaltite (i.e., $\mathrm{SSC}$, $\mathrm{Sm}_{0.5} \mathrm{Sr}_{0.5} \mathrm{CoO}_{3}$ ) electrodes.

SDC powders were prepared with nitrate reagents according to the pechini method. Cerium nitrate $99.5 \%$, samarium nitrate $99.9 \%$, ethylene glycol $99+\%$ and citric acid monohydrate ACS $99.0 \%$ were purchased from Alfa Aesar and used without further purification. Stoichiometric amounts of each metal nitrate were weighted and dissolved in water at room temperature. The resulting material was mixed with a solution of citric acid and ethylene glycol (1.88 molar metal to citric acid ratio), and was allowed to undergo three consecutive steps: polymerization, solvent removal, and calcination. 
In a typical SDC synthesis, $3.09 \mathrm{~g}$ of cerium nitrate and $0.79 \mathrm{~g}$ of samarium nitrate were weighted and dissolved in deionized water at room temperature. In a separate beaker, $5.86 \mathrm{~g}$ of a solution containing citric acid and ethylene glycol (60\% wt citric acid) was prepared. The above two solutions were then mixed under vigorous stirring at $70{ }^{\circ} \mathrm{C}$. The resulting mixture was further heated to $90{ }^{\circ} \mathrm{C}$ and was allowed to react for several hours until yielding a yellowish foam. The obtained foam was removed from the beaker, placed in an alumina crucible, and calcined at $450{ }^{\circ} \mathrm{C}$ for $5 \mathrm{~h}$ at a heating rate of $5{ }^{\circ} \mathrm{C} / \mathrm{min}$. Finally, the material was crushed using a hand and pestle mortar to obtain a fine cream colored powder. The resulting SDC powder was dried milled for $24 \mathrm{~h}$ using a rotary ball milling device using a plastic container with ceramic grinding balls. The obtained material was dried for $2 \mathrm{hr}$ at $120^{\circ} \mathrm{C}$, passed through a \#120 sieve (125 $\mu \mathrm{m}$ size), and then calcined at $900^{\circ} \mathrm{C}$ for $6 \mathrm{hr}$ at a heating rate of $5{ }^{\circ} \mathrm{C} / \mathrm{min}$.

SSC $\left(\mathrm{Sm}_{0.5} \mathrm{Sr}_{0.5} \mathrm{CoO}_{3}\right)$ powders were prepared using oxide reagents. Samarium (III) oxide 99.9\%, cobalt oxide (II, III) 99\%, and strontium carbonate $99.99 \%$ were purchased from Alfa Aesar and were used without further purification. Typical SSC synthesis involves use of $2.32 \mathrm{~g}$ of samarium oxide, $3.20 \mathrm{~g}$ of cobalt oxide and $0.98 \mathrm{~g}$ of strontium carbonate mixed in methanol. The resulting mixture was wet ball milled for $24 \mathrm{~h}$ using a plastic container and ceramic grinding balls. The obtained material was dried for $2 \mathrm{hr}$ at $120^{\circ} \mathrm{C}$ and then calcined at $800{ }^{\circ} \mathrm{C}$ for $6 \mathrm{hr}$ at a heating rate of $5{ }^{\circ} \mathrm{C} / \mathrm{min}$.

The fuel cell materials were further processed by adding a PVB (Poly Vinyl Butyral) based organic binder and a number of additives including dispersant and solvent in order to enhance the strength of the ceramic green body. The amounts of additives such as binder, a dispersant, and a mixture of solvents were varied to obtain an optimum green body. In a typical green body preparation, $2.0 \mathrm{~g}$ of the fuel cell starting material (SDC or SSC) were weighted and 
added to a solution containing a dispersant and a solvent at room temperature. The obtained slurry was subsequently grinded (wet milling) in a $3 \mathrm{lb}$ laboratory ball mill containing zirconia balls for $7 \mathrm{~h}$. The resulting material was further mixed with binder and solvent and grinded for three more hours. The resulting slurry was dried at room temperature for $2 \mathrm{~h}$ and finally re crushed using a hand and pestle mortar in to a fine powder form. The SDC was cold pressed in the form of a thin disc and calcined at $1500{ }^{\circ} \mathrm{C}$. The sintered SDC disc was screen-printed with SSC as a cathode and an oxide material as anode.

Both current and voltage output data from the fuel cell were acquired by a PC with an interface and Labview ${ }^{\mathrm{TM}}$ software. The gaseous product was analyzed by a SRI $8610 \mathrm{C}$ gas chromatograph and a Pfeiffer QMS 200 mass spectrometer. The analysis of gaseous products, such as $\mathrm{CO}$ and $\mathrm{CO}_{2}$, allows the determination of the fuel conversion efficiency and byproduct formation. 


\section{RESULTS AND DISCUSSION}

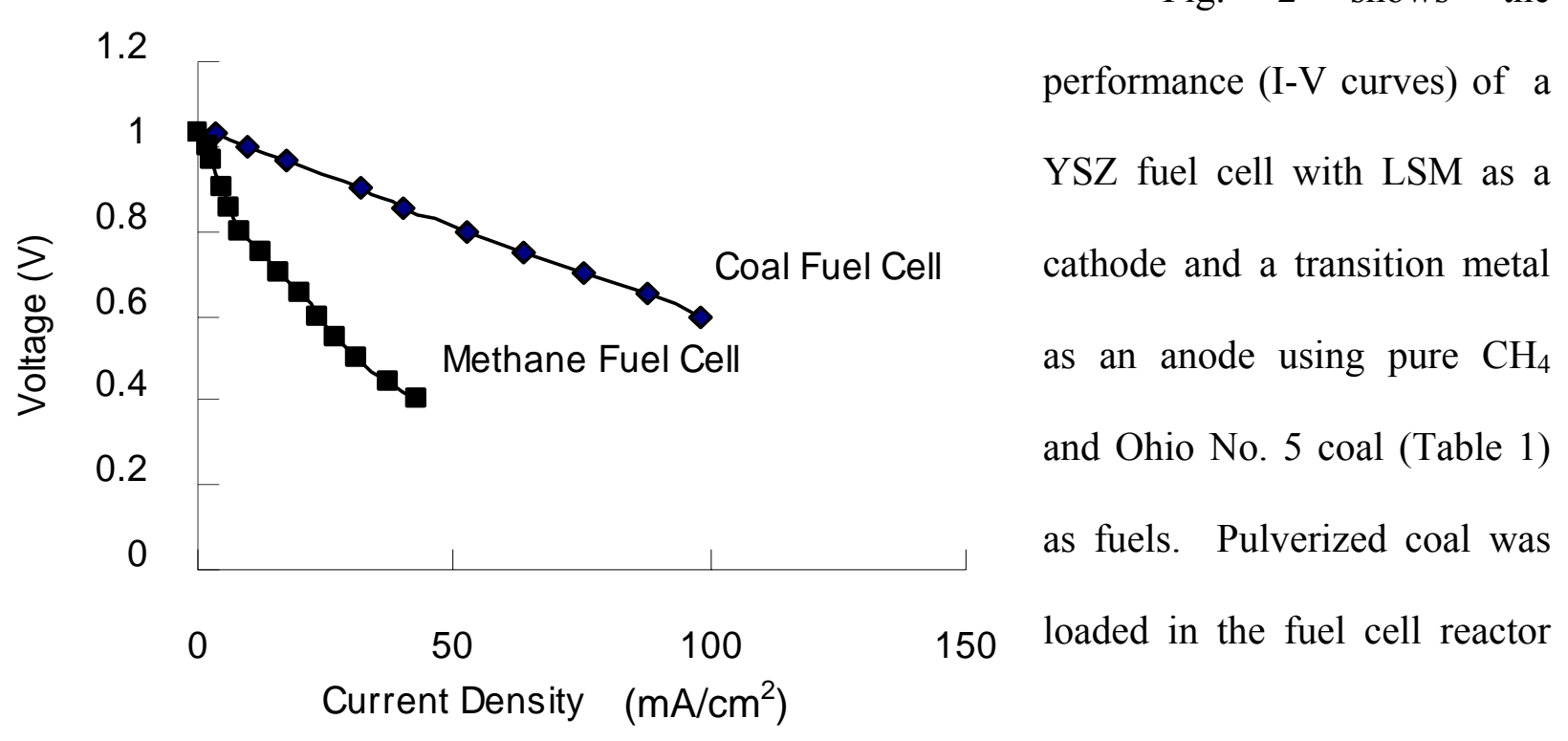

Figure 2. I-V curves of a YSZ fuel cell

tube and was gradually heated to $950{ }^{\circ} \mathrm{C}$. The $\mathrm{C}$ - fuel cell at $950{ }^{\circ} \mathrm{C}$ produced higher current density than that for the $\mathrm{CH}_{4}$-fuel cell. It is remarkable to observe that the current-voltage (I-V) curve for coal is higher than that for methane. Comparison of $\mathrm{CH}_{4} \mathrm{I}-\mathrm{V}$ curve in Fig. 2 with those in literature (7-15) shows that the current density for $\mathrm{CH}_{4}$ is about $35 \%$ of the best reported data for the direct methane SOFC. This is due to the use of thicker solid YSZ electrolyte (i.e, $1 \mathrm{~mm}$ in thickness) in our fuel cell as compared with $50 \mu \mathrm{m}$ in the literature.

Table 1 Ohio coal no. 5 (PSOC-1517)

\begin{tabular}{|c|c|c|c|c|c|}
\hline \multicolumn{4}{|c|}{ PROXIMATE ANALYSIS } & \multicolumn{2}{|l|}{ ULTIMATE ANALYSIS } \\
\hline \multicolumn{3}{|c|}{$\%$ Moisture as received } & 4.15 & $\%$ Carbon & 83.99 \\
\hline \multicolumn{3}{|l|}{ Dry $\%$ ash } & 4.80 & $\%$ Hydrogen & 5.50 \\
\hline \multicolumn{3}{|c|}{ Dry $\%$ volatile matter } & 37.98 & $\%$ Nitrogen & 1.88 \\
\hline \multicolumn{3}{|c|}{ Dry $\%$ fixed carbon } & 57.22 & $\%$ Oxygen & 8.63 \\
\hline \multicolumn{4}{|c|}{ SULFUR FORMS } & CALORIFIC VALUE (BTU/lb) & 14258 \\
\hline$\%$ Pyritic & 0.70 & $\%$ Organic & 1.21 & & \\
\hline$\%$ Sulfate & 0.01 & $\%$ Total & 1.92 & EQULIBIRUM MOISTURE (\%) & 7.98 \\
\hline
\end{tabular}


The analysis of the gaseous stream showed that the major product produced from the coal fuel cell is $\mathrm{CO}_{2}$ with less than $5 \%$ of $\mathrm{CO}$. $\mathrm{CO}$ concentration can be further decreased by decreasing the flow rate of Ar which was used to bring out the gaseous product for the analysis. $\mathrm{SO}_{2}$ was only observed during heating of coal. $\mathrm{SO}_{2}, \mathrm{CO}, \mathrm{H}_{2}$ and $\mathrm{CH}_{4}$ begin to form at $400^{\circ} \mathrm{C}$. The concentration of $\mathrm{SO}_{2}$ in the fuel cell effluent reached a peak at $650{ }^{\circ} \mathrm{C}$ and then declined with temperature. As the temperature reached $750{ }^{\circ} \mathrm{C}$, the concentration of $\mathrm{SO}_{2}$ in the fuel cell effluent decreased to zero, indicating that most of the organic sulfur has left the coal in the fuel cell. It is important to note that coal undergoes devolatilization as it is exposed to temperatures above $400{ }^{\circ} \mathrm{C}$. Under the operating temperature (i.e., $600-950{ }^{\circ} \mathrm{C}$ ) of the $\mathrm{SOFC}$, coal is in the form of coke.

Fly ash produced from coal did not strongly adhere onto the anode catalyst surface. This observation is indeed remarkable, considering that the fly ash deposition and slagging are major concerns in the design of coal-fired boilers. Examination of the physical properties of the fly ash and its formation history revealed that the reason for fly ash not fusing on the anode catalyst surface could be that our fuel cell operation temperature is lower than the fly ash fusibility temperature. $^{3}$ Analysis of fly ash by Galbraith laboratory showed that no sulfur was present in the fly ash. Repeated runs for more than 2 hours at $950{ }^{\circ} \mathrm{C}$ on the same fuel cell gave the same level of electric power as that in the first run.

The high efficiency of carbon or coal fuel cells has been pointed out by Cooper who has performed thermodynamic analysis. ${ }^{1}$ Results of the analysis of a pilot carbon fuel cell plant in Table 2 showed that the carbon fuel cell has a highest total efficiency because of the favorable thermodynamics of the carbon-oxygen reaction. It is important to note that the theoretical limit of carbon fuel is greater than one because $\Delta \mathrm{G}$ for carbon oxidation is greater than $\Delta \mathrm{H}$. The high 
value of $\Delta \mathrm{G}$ (i.e., $\Delta \mathrm{G}(\mathrm{T})=\Delta \mathrm{H}-\mathrm{T} \Delta \mathrm{S}$ ) can be attributed to the reaction of solid carbon with oxygen to produce gaseous $\mathrm{CO}_{2}$ and $\mathrm{H}_{2} \mathrm{O}$. The reaction involved with solid carbon contributes to $\Delta \mathrm{G}$ through a significant increase in $\Delta \mathrm{S}$. This is in contrast to $\mathrm{CH}_{4}$ and $\mathrm{H}_{2}$ fuel cell reactions which involve gaseous reactant and gaseous product, giving little change in $\Delta \mathrm{S}$.

Cooper further pointed out that the chemical potential for the carbon is constant and independent of the extent of its conversion or position within the fuel cell because the reactant carbon and product $\mathrm{CO}_{2}$ exist as pure substances in separate phases. ${ }^{2}$ In principle, this allows all the carbon fuel to be completely consumed in a single pass. The above analysis and our results show that that the direct use of coal as a fuel for the solid oxide fuel cell is both theoretically and technically feasible for power generation.

Table 2 Efficiency of solid oxide fuel cell

\begin{tabular}{lllll}
\hline Fuel & $\begin{array}{l}\text { Theoretical } \\
=\Delta \mathrm{G}^{\circ}(\mathrm{T}) / \Delta \mathrm{H}^{\circ}(\mathrm{T}) \mathrm{std}\end{array}$ & $\begin{array}{l}\text { Utilization } \\
\text { Efficiency, } \mu\end{array}$ & $\begin{array}{l}\mathrm{V}(\mathrm{i}) / \mathrm{V}(\mathrm{i}=0) \\
=\varepsilon \mathrm{V}\end{array}$ & $\begin{array}{l}\text { Actual } \\
=\left(\Delta \mathrm{G} / \Delta \mathrm{H}^{\circ} \mathrm{std}\right)(\mu)(\varepsilon \mathrm{V})\end{array}$ \\
\hline $\mathrm{C}$ & 1.003 & 1.0 & 0.8 & 0.8 \\
$\mathrm{CH}_{4}$ & 0.895 & 0.8 & 0.8 & 0.57 \\
$\mathrm{H}_{2}$ & 0.70 & 0.8 & 0.8 & 0.45 \\
\hline
\end{tabular}

Efficiency of a fuel cell or battery is defined :

$=($ Electrical energy out) $/$ (Heat of combustion (HHV) of fuels input)

$=[$ Theoretical efficiency $\mathrm{G} / \mathrm{H}][\mathrm{Utilization}$ fraction $\mu][$ Voltage efficiency $\varepsilon \mathrm{v}]$

$=\left[\Delta \mathrm{G}(\mathrm{T}) / \Delta \mathrm{H}^{\circ}\right][\mu]\left[\mathrm{V} / \mathrm{V}^{\circ}\right]=[\mu][\mathrm{nFV}] / \Delta \mathrm{H}^{\circ}$

-- where $\Delta \mathrm{G}(\mathrm{T})=-\mathrm{nFV}^{\circ}=\Delta \mathrm{H}-\mathrm{T} \Delta \mathrm{S}$

To further confirm the feasibility of the use of solid fuel and the requirement of sulfur resistance, we have prepared a Ni-based anode catalyst by impregnation of YSZ fibers (Zircar) and YSZ powder (Tosoh) in 7:3 ratio with $\mathrm{Ni}\left(\mathrm{NO}_{3}\right)_{2}$ and a transition metal precursor. The transition metal was added onto the Ni-anode to enhance its resistance to sulfur poisoning and coking. The Ni-based anode material was pasted on the anode side of YSZ disc $(1 \mathrm{~mm})$ using 
glycerine and calcined at $1000^{\circ} \mathrm{C}$ for 4 hours. The cathode material was prepared by mixing Lanthanum Strontium Manganese Oxide (LSM) and YSZ powder in 1:1 ratio.

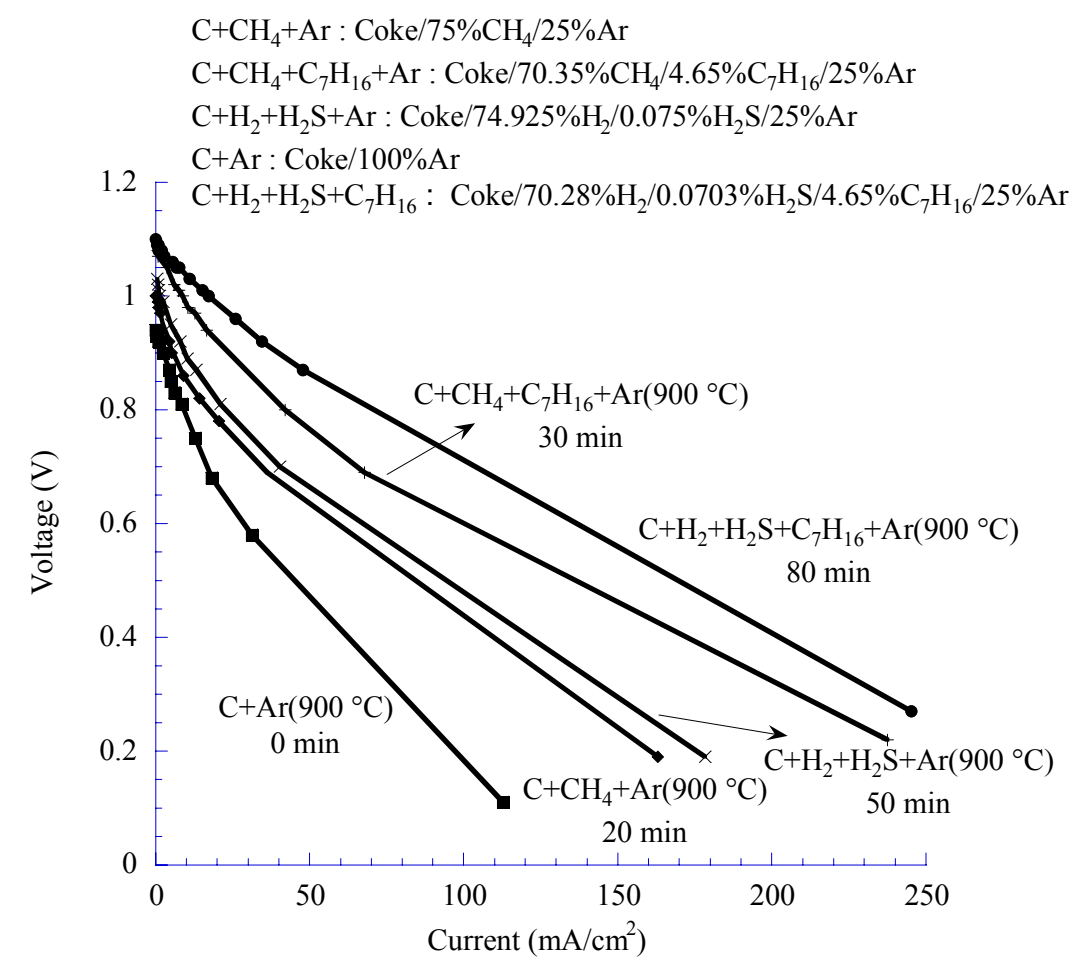

Figure 3. $\mathrm{I}-\mathrm{V}$ for petroleum coke and fuel mixtures for a Ni-based anode SOFC at $900{ }^{\circ} \mathrm{C}$
Fig. 3 shows the I-V curves of a Ni-based anode SOFC taken at $900{ }^{\circ} \mathrm{C}$ using petroleum coke provided by FirstEnergy at Akron. The petroleum coke consists of $81 \%$ carbon, $3 \%$ hydrogen, $1 \%$ nitrogen, $4.6 \%$ sulfur, $0.2 \%$ ash, $10 \%$ moisture, $330 \mathrm{ppm}$ $\mathrm{Ni}, 84 \mathrm{ppm} \mathrm{Fe}$, and less than 2000 ppm Vanadium. The current density at $900{ }^{\circ} \mathrm{C}$ increased in the order: coke $<$ coke $/ \mathrm{CH}_{4}<$ coke $/ \mathrm{H}_{2} / \mathrm{H}_{2} \mathrm{~S}<$ coke $/ \mathrm{CH}_{4} / \mathrm{C}_{7} \mathrm{H}_{16}$. The low open circuit voltage and the large decrease in the I-V curve at the low current density region suggest a significant activation polarization for petroleum coke as compared with other fuel mixtures.

Increasing the temperature to $950{ }^{\circ} \mathrm{C}$ led to a further increase in the current density (Fig. 4). It is interesting to observe that all the I-V curves were merged together, giving the same slope. These results suggest that the Ohmic resistance is dominated in these fuel cell operations and all the fuel and fuel mixtures gave the same level of activation polarization. The Ohmic resistance primarily resulted from the resistance of $\mathrm{O}^{2-}$ conduction over the electrolyte. 


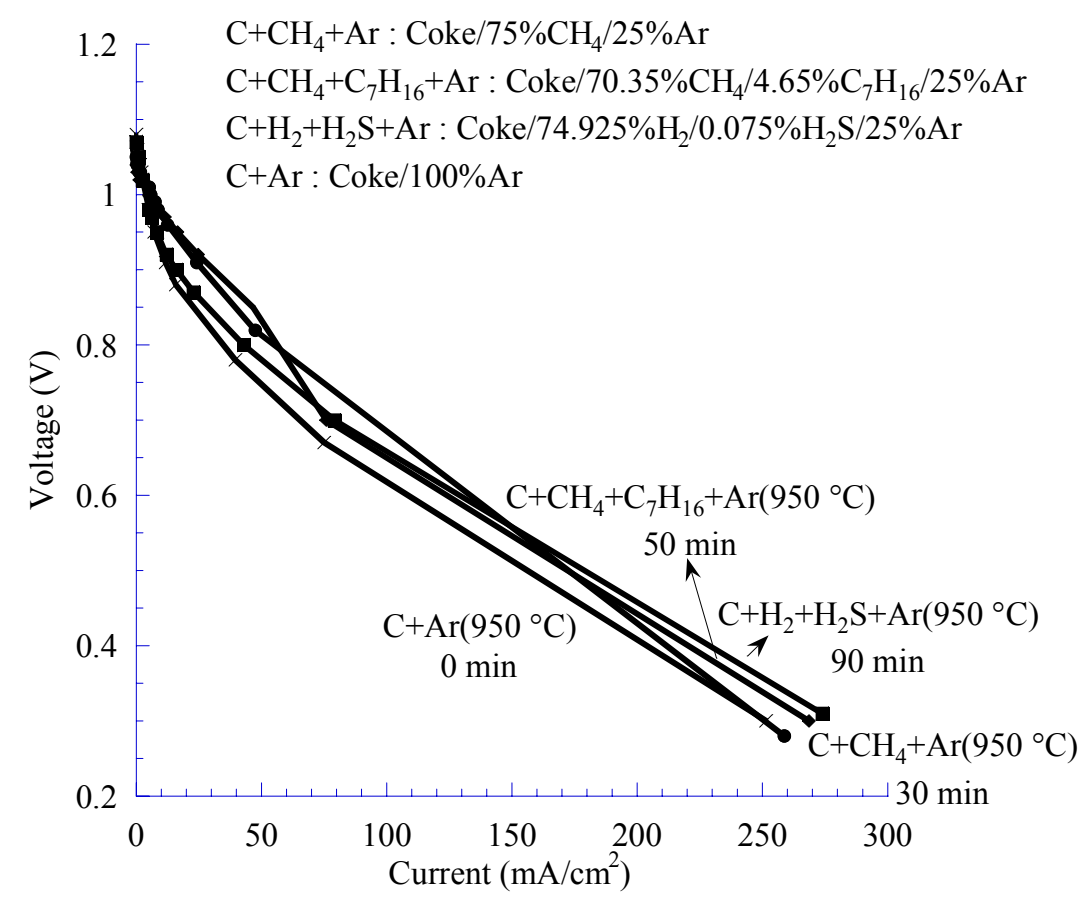

Figure 4. I-V for petroleum coke and fuel mixtures for a Nibased anode $\mathrm{SOFC}$ at $950{ }^{\circ} \mathrm{C}$
Decreasing the thickness of the electrolyte could lead to a significant improvement of the current density by increasing $\mathrm{O}^{2-}$ flux. An alternative to enhance the $\mathrm{O}^{2-}$ flux is to search for a fluorite oxide electrolyte with low temperature and high oxygen anion conductivity.

It is interesting to note that $\mathrm{H}_{2} \mathrm{~S}$ did not lead to any deactivation of the anode Ni-based catalyst. The failure of $\mathrm{H}_{2} \mathrm{~S}$ to poison the anode is due to the presence of a transition metal oxide which is known to impart its sulfur resistance to the $\mathrm{Ni}$ catalyst in the petroleum refining process. ${ }^{16}$ 
Figure 5. IV of a SDC fuel cell

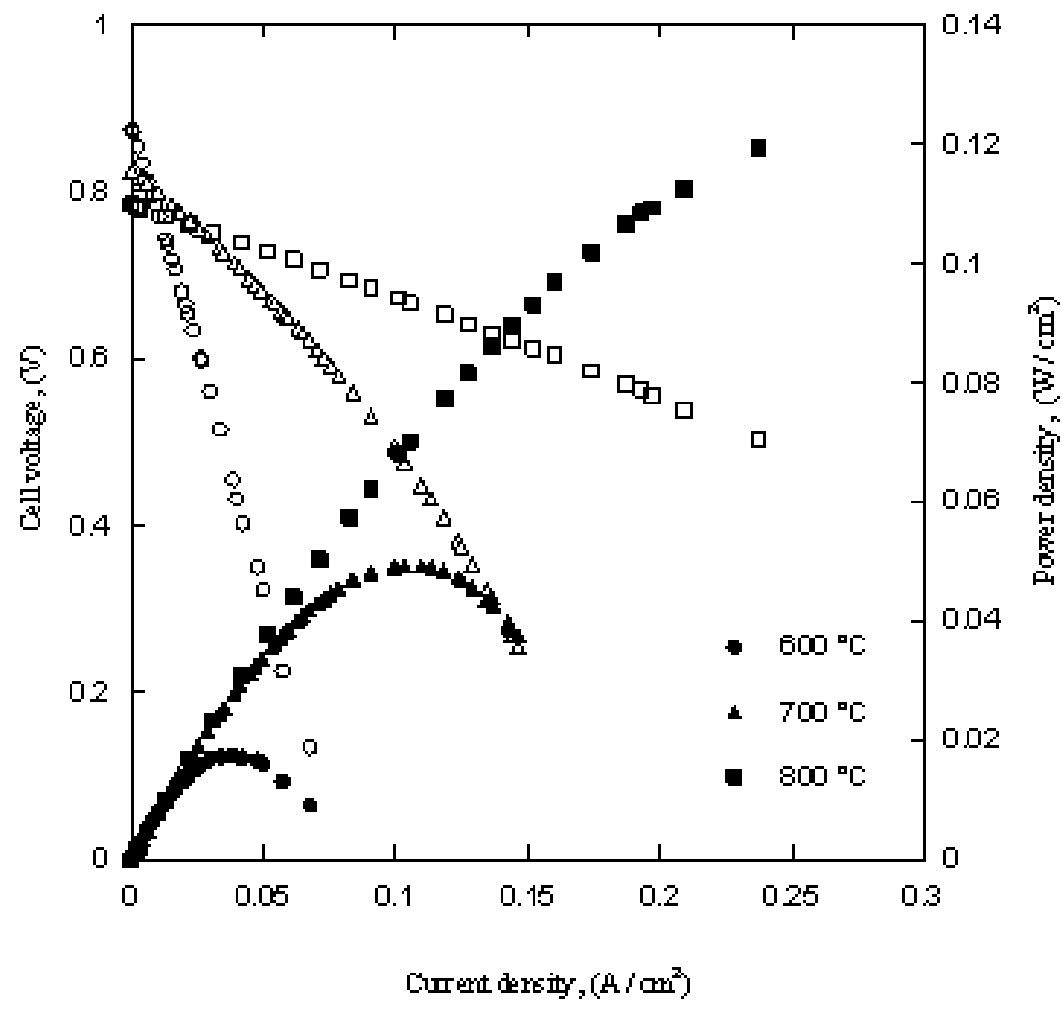

SDC was selected as a potential electrolyte for the carbon fuel cell due to its high oxygen anion conductivity at low temperature. Figure 5 show the I-V curve of a SDC fuel cell using SSC as cathode and Pt metal as an anode with flowing a mixture of 12.5 $\mathrm{cc} / \mathrm{min}$ of $\mathrm{He}$ and $12.5 \mathrm{cc} /$

min of $\mathrm{H}_{2}$ saturated at room temperature with $\mathrm{H}_{2} \mathrm{O}\left(3 \%\right.$ volume $\left.\mathrm{H}_{2} \mathrm{O}\right)$. Comparison of SDC with YSZ fuel cell in electricity output suggests that the use of SDC electrolyte may lead to an enhancement of the current density of the direct carbon fuel cell. 


\section{CONCLUSIONS}

The key observations and results obtained from Phase I research are summarized below:

- The activity of the metal/metal oxide anode catalysts for catalyzing the electrochemical oxidation of coal, petroleum coke, $\mathrm{CH}_{4}$, and heptane depends on the composition of the anode catalyst

- A promoted Ni-based anode catalyst exhibits sulfur resistance and a good activity for electrochemical oxidation of heptane and $\mathrm{H}_{2} \mathrm{~S}$.

- Fly ash produced from coal did not strongly adhere onto the anode catalyst surface.

- SDC could serve as an electrolyte to enhance the current density of the carbonfuel cell.

The key issues to be addressed prior to scale up include (i) enhancement of power density and (ii) removal of fly ash. The former requires identification of the lead anode catalyst, optimization of the catalyst compositions and structure, and enhancement of $\mathrm{O}^{2-}$ diffusion rate across the solid electrolyte. Removal of fly ash calls for an ingenious design of the fuel cell reactor system.

\section{REFERENCES}

1 J. Cooper, Lawrence Livermore National Laboratory, Livermore CA, 2003, http://www.llnl.gov/str/June01/pdfs/06 01.1.pdf

2 J. F. Cooper, International Conference on Fuel Cell Science, Engineering and Technology, 2004.

3 'STEAM in generation and use', A Handbook of Babcock \& Wilcox, 40th Edition, 1992.

4 A. Hamnett and P. Christensen, in 'Electrochemical and Photoelectrochemical Energy Conversion', ed. N. Hall, Cambridge, 2000.

5 A. J. Appleby and F. R. Foulkes, 'Fuel Cell Handbook', Van Nostrand Reinhold, 1989.

6 Y. H. Huang,"Soft Chemical Synthesis and Transport propierties of La0.7Sr0.3MnO3 Granular Perovskites" Solid State Communications, 2000, 114, 43. 
7. S. A. Barnett, in 'Direct hydrocarbon SOFCs', ed. W. Vielstich, H. A. Gasteiger, and A. Lamm, New York, 2003.

$8 \quad$ R. J. Gorte, S. Park, J. M. Vohs, and C. Wang,"Anodes for direct oxidation of dry hydrocarbons in a solid-oxide fuel cell" Advanced Materials (Weinheim, Germany), 2000, 12, 1465.

9 R. J. Gorte and J. M. Vohs,"Novel SOFC anodes for the direct electrochemical oxidation of hydrocarbons" Journal of Catalysis, 2003, 216, 477.

10 T. Hibino, A. Hashimoto, M. Suzuki, and M. Sano,"A solid oxide fuel cell using Y-doped $\mathrm{BaCeO} 3$ with $\mathrm{Pd}$-loaded $\mathrm{FeO}$ anode and $\mathrm{Ba} 0.5 \mathrm{Pr} 0.5 \mathrm{CoO} 3$ cathode at low temperatures" Journal of the Electrochemical Society, 2002, 149, A1503.

11 T. Hibino, A. Hashimoto, M. Yano, M. Suzuki, S.-I. Yoshida, and M. Sano,"High performance anodes for SOFCs operating in methane-air mixture at reduced temperatures" Journal of the Electrochemical Society, 2002, 149, A133.

12 T. Hibino, T. Hashimoto, T. Inoue, J.-I. Tokuno, S.-I. Yoshida, and M. Sano,"A lowoperating-temperature solid oxide fuel cell in hydrocarbon-air mixtures" Science (Washington, D. C.), 2000, 288, 2031.

13 B. C. H. Steele,"Appraisal of Ce1-yGdyO2-y/2 electrolytes for IT-SOFC operation at 500 DegC" Solid State Ionics, 2000, 129, 95.

14 B. C. H. Steele, P. H. Middleton, and R. A. Rudkin,"Material science aspects of SOFC technology with special reference to anode development" Solid State Ionics, 1990, 40-41, 388.

15 S. A. Barnett, 'Handbook of Fuel Cells', ed. A. L. W. Vielstich, H. A. Gasteiger, Wiley, 2003.

16 B. C. Gates, 'Catalytic Chemistry', Wiley, 1992. 


\section{LIST OF ACRONYMS AND ABBREVIATIONS}

C-fuel cell: carbon-based fuel cell

SOFC: solid oxide fuel cell

SDC: Samarium-doped Ceria $\left(\mathrm{Sm}_{0.2} \mathrm{Ce}_{0.8} \mathrm{O}_{1.9}\right)$

SSC: Strontium-doped Samarium Cobaltite $\left(\mathrm{Sm}_{0.5} \mathrm{Sr}_{0.5} \mathrm{CoO}_{3}\right)$

YSZ: Yittria-stabilized zirconia

LSM: $\mathrm{La}_{0.7} \mathrm{Sr}_{0.3} \mathrm{MnO}_{3}$ 